\title{
Effects of Clover-Grass Silages and Concentrate Supplementation on the Content of Phytoestrogens in Dairy Cow Milk
}

\author{
H. Steinshamn, ${ }^{* 1}$ S. Purup, $†$ E. Thuen, $\ddagger$ and J. Hansen-Møller† \\ ${ }^{*}$ Organic Food and Farming Division, Norwegian Institute for Agricultural and Environmental Research, Tingvoll gard, N-6630 Tingvoll, Norway \\ †Department of Animal Health, Welfare and Nutrition, Faculty of Agricultural Sciences, University of Aarhus, Blichers Allé 20, Post Box 50, \\ DK-8830 Tjele, Denmark \\ ‡Department of Animal and Aquacultural Sciences, Norwegian University of Life Sciences, PO Box 5003, N-1432 Ås, Norway
}

\begin{abstract}
A $2 \times 2$ factorial continuous experiment was conducted with 28 Norwegian Red dairy cows in early lactation to compare milk content of phytoestrogens when feeding ad libitum white clover (WCS) or red clover (RCS) grass silages prepared from the second and third cut without and with $10 \mathrm{~kg} / \mathrm{d}$ supplementation of a standard concentrate. The cows were offered either RCS or WCS for $88 \mathrm{~d}$ (period 1) and thereafter a mixed red clover-white clover-grass silage for $48 \mathrm{~d}$ (period 2). Total dry matter intake and milk yield were not affected by forage type but increased with concentrate supplementation. Intake of isoflavones was several times greater in RCS than in WCS, whereas intake of lignans was greater in WCS. Concentrate supplementation reduced the intake of most phytoestrogens. Compared with WCS, RCS diets yielded milk with a greater content of flavonoids, whereas milk from WCS diets had greater contents of the mammalian lignans enterodiol and enterolactone. The content of the isoflavan equol was particularly high in RCS diets. There was no apparent carryover effect of clover type on milk phytoestrogen content because there was no difference in content between the silage treatments 3 wk after the cows were transferred to the same silage diet (period 2). Concentrate supplementation reduced the milk contents of the flavonoids equol, biochanin A, and daidzein and increased the content of mammalian lignans. The effects of silage type and concentrate supplementation on milk contents of the individual phytoestrogens were related to the intake of the compound or its precursor, except for the effect of concentrate on mammalian lignans, for which the intake of the known precursors was also reduced. Overall, this study shows that feeding cows with silage containing red clover increases the milk content of flavonoids at both low and high concentrate
\end{abstract}

Received November 13, 2007.

Accepted March 3, 2008.

${ }^{1}$ Corresponding author: havard.steinshamn@bioforsk.no supplementation levels, and decreases the content of nonflavonoids such as mammalian lignans, when compared with silage containing white clover. The increased content of phytoestrogens in milk may be important when the health benefits of milk are studied. Key words: clover species, concentrate level, milk phytoestrogen content, equol

\section{INTRODUCTION}

Interest has increased in the dietary content and intake of phytoestrogens that have a chemical structural similarity to mammalian estrogen (17 $\beta$-estradiol). Because of their similarity, the phytoestrogens may compete with estrogens to bind to estrogen receptors, and therefore may act as weak estrogen agonists or antagonists (Tham et al., 1998). Because of these properties, phytoestrogens have potential effects on health, as indicated in epidemiological studies and experimental data from animal studies. The benefits for human health are that they may protect against diseases such as breast and prostate cancer, cardiovascular diseases, osteoporosis, and menopausal symptoms (Adlercreutz et al., 1991; Cornwell et al., 2004). However, it should be noted that high dietary intake of phytoestrogens is also questioned for having adverse health effects, for instance, in critical stages of infant development (Zung et al., 2001; Mendez et al., 2002; Tuohy, 2003). Therefore, the timing of exposure to phytoestrogens may be important for the potential health benefits, as also suggested with estrogens (Hilakivi-Clarke et al., 2001).

The research on phytoestrogens and their potential benefits for humans has focused on the occurrence and the effects of these substances from vegetables. There are few studies on food products of animal origin. Ruminant feedstuffs may contain phytoestrogens, and the focus in animal nutrition has historically been on their fertility-disordering effects (Bennetts et al., 1946; Kallela et al., 1984; Adams, 1995). The phytoestrogens in feedstuffs are mainly lignans and flavonoids, including isoflavones, coumestans, and phenyl flavonoids. The 
primary plant lignans, secoisolariciresinol (Seco) and matairesinol (Mata), are found in the cereals, legumes, and oilseeds used in concentrates (Thompson et al., 1991; Adlercreutz and Mazur, 1997). Seco and Mata are metabolized to enterodiol and enterolactone, respectively, by the gut microflora, and enterodiol is further oxidized to enterolactone (Borriello et al., 1985). These lignans are absorbed into circulation by the intestinal cells. The other large phytoestrogen group, the flavonoids, is predominantly found in legumes, both in grain legumes and in grassland legumes such as clovers. In grain legumes, the prevailing isoflavones are daidzein and genistein, whereas in grassland clovers formononetin and biochanin A dominate (Saloniemi et al., 1995; $\mathrm{Wu}$ et al., 2003). When consumed, isoflavonoids are metabolized by the rumen and gut flora (formononetin to daidzein and further to equol), whereas biochanin A is metabolized to genistein and further to $p$-ethyl phenol (Cox and Braden, 1974; Dickinson et al., 1988; Lundh, 1990). The content of isoflavonoids varies among plant species, with the total content being much higher in red clover (Trifolium pratense L.) than in white clover (Trifolium repens L.; Saloniemi et al., 1995; Wu et al., 2003). Environmental factors, cultivars, stage of maturity, and plant parts also influence the content of isoflavonoids (McMurray et al., 1986; Sivesind and Seguin, 2005). The coumestans, of which coumestrol is the most common form, are mainly found in legumes such as clover, alfalfa, and soybean sprouts (Smith and Jagusch, 1979; Cornwell et al., 2004).

Although the content of phytoestrogens in foods of plant origin has been investigated extensively, only a few studies have been carried out to investigate their content in products of animal origin, such as bovine milk, and factors that may influence this content. King et al. (1998) found generally low contents in milk samples collected on farms in Australia. Antignac et al. (2004) in France and Hoikkala et al. (2007) in Finland analyzed commercial milk products, and both studies revealed that milk from organically managed dairy farms had a greater content of isoflavonoids than did conventionally produced milk. Purup et al. (2005) also found a greater content of isoflavonoids in bulk milk from organically managed dairy farms than from conventionally managed dairy farms, presumably because of the greater use of legumes in the cows' diet on organic farms. However, less is known about how grassland clover species in silage and concentrate supplementation level influence the content and composition of phytoestrogens in bovine milk and the transfer rate of phytoestrogens from feed to milk. Therefore, the hypothesis to be tested was that cows offered red clover-grass silage (RCS) would have greater content of isoflavonoids in milk than those fed white clover-grass silage (WCS).
Additionally, concentrate supplementation could reduce the milk content of flavonoids by reducing the intake of silage, but could increase the content of lignans through a higher intake of grain.

\section{MATERIALS AND METHODS}

\section{Animals and Experimental Design}

Twenty-eight autumn-calving Norwegian Red cows (574 $\pm 48 \mathrm{~kg}$ of BW; $3.1 \pm 1.91$ number of lactations) were blocked according to calving date and parity. Cows were assigned to a $2 \times 2$ factorial arrangement of treatments, with the main factors being type of silage (RCS = red clover-grass silage; WCS $=$ white clover-grass silage) and concentrate supplementation (none $=0$; yes $=$ 1) but were kept as one flock in a free-stall barn. All cows were on pasture during the dry period before onset of the experiment; they were housed approximately 3 wk before expected calving and were then fed grassclover silage ad libitum until onset of the experiment. Animals started the silage type treatments (WCS or RCS) on October 3, 2005, at an average of $2 \pm 18$ DIM, when 16 of the 28 cows had calved. The remaining cows calved within $5 \mathrm{wk}$. The experiment lasted until December 31, 2005 (period 1, 88 d). Thereafter (period $2 ; 48 \mathrm{~d}$, starting on January 1, 2006), all cows, irrespective of the silage treatment group, were offered secondcut grass-clover silage but concentrate supplementation as in period 1. Concentrate supplementation started from 2 to $3 \mathrm{wk}$ before expected calving and was kept at a constant rate of $2 \mathrm{~kg} / \mathrm{d}$ and cow until the second day after parturition, when it was increased at a rate of $0.5 \mathrm{~kg} / \mathrm{d}$ and cow to $10 \mathrm{~kg} / \mathrm{d}$, kept constant for $90 \mathrm{~d}$, and thereafter reduced to zero after 200 DIM. The procedures in the experiment were approved by the Norwegian Animal Research Authority, Oslo, Norway.

\section{Feeds}

White clover (T. repens L. cvs. 'Milkanova' and 'Sonja') and red clover ( $T$. pratense L. cvs. 'Bjursele' and 'Nordi') were sown separately but together with grasses (Phleum pratense cv. 'Gindstad', Festuca pratensis cv. 'Fure', and Lolium perenne cv. 'Napoleon') in May 2003 on 3 replicated fields, with barley as the cover crop, and were managed according to organic standards. At the time of sowing, dairy manure was applied at a rate of approximately 20 t/ha. During the subsequent production years, no animal manure or fertilizer was applied. The second and third cuts in 2005 were harvested with a disc mower, wilted without spreading, and ensiled in round bales (1.2 m diameter, $1.2 \mathrm{~m}$ height, and fresh weight of $769 \pm 64.5 \mathrm{~kg}$ ). A potassium formate-based additive (GrasAAT Eco, Yara Formates AS, Porsgrunn, 
Norway) was applied to all crops at the average rate of $3.9 \mathrm{~L} / \mathrm{t}$ of crop. Mixtures of the second- and third-cut silages prepared from each crop were used as the experimental feed in period 1 to ensure that feeds were more representative of the crop type. Bales were chopped and mixed just before feeding. The clover, grass, and weed proportions of DM yield were $0.26,0.67$, and 0.07 in the second cut and $0.35,0.61$, and 0.04 in the third cut of the white clover-grass ley, respectively, and were $0.29,0.67$, and 0.04 in the second cut and $0.42,0.56$, and 0.02 in the third cut of the red clover-grass ley, respectively. The weed fraction was mainly unsown grasses.

The silage offered between pasture grazing and onset of the experiment was a mixture of the experimental forages prepared from the first cut, with average DM proportions of 0.08 red clover and 0.05 white clover. In period 2, the silage used was prepared from second-cut organically managed leys containing both red clover and white clover in addition to grass species. All silages were fed ad libitum. All cows also received approximately $1 \mathrm{~kg}$ of hay per day, prepared from a grassdominated organically managed ley cut at the early blooming stage of $P$. pratense $\mathrm{L}$.

The concentrate supplement was an organic standard concentrate mixture (Natura Drøv 10, Felleskjøpet Agri, Oslo, Norway) and was offered through automatic feeders. The mixture consisted of $(\mathrm{g} / \mathrm{kg})$ oats $(600)$, barley (260), fish meal (70), sugar cane molasses (40), and minerals-vitamins (30). The mineral-vitamin premix supplied (on a concentrate DM basis): 5,643 IU of vitamin $\mathrm{A} / \mathrm{kg}, 2,257 \mathrm{IU}$ of vitamin $\mathrm{D}_{3} / \mathrm{kg}, 56 \mathrm{mg} / \mathrm{kg}$ of vita$\mathrm{min} \mathrm{E,} 11 \mathrm{mg} / \mathrm{kg}$ of $\mathrm{Cu}, 0.28 \mathrm{mg} / \mathrm{kg}$ of Se, $73 \mathrm{mg} / \mathrm{kg}$ of $\mathrm{Zn}, 2.3 \mathrm{mg} / \mathrm{kg}$ of I, and $0.23 \mathrm{mg} / \mathrm{kg}$ of Co (Table 1 ).

\section{Data Collection and Sampling Procedures}

Cows were milked 2 times each day. Feed intake, animal live weight, and milk yield were recorded daily automatically by intake-recording feeders (forage: BioControl AS, Rakkestad, Norway; concentrates: DeLaval Alpro, Tumba, Sweden), electronic weighing (live weight: Welvaarts BV, Den Dungen, the Netherlands), and a milk-monitoring system (milk yield: DeLaval, Alpro, Tumba, Sweden). Every 4 wk, starting 3 wk after the onset of feeding the experimental silage, milk samples were collected from 6 consecutive milkings and pooled into 1 sample per cow. In total, 5 samples were collected per cow: 3 samples per cow during period 1 (the silage experimental period) and 2 samples per cow in period 2 (the period after termination of the silage treatment). Six cows had not calved at the first sampling date in period 1 , and one sample taken from the first sampling date in period 2 was lost from one cow.
Therefore, 133 samples were analyzed. Milk samples were frozen immediately after collection and stored at $-20^{\circ} \mathrm{C}$ until analysis for phytoestrogens.

Silage, concentrate, and hay samples were collected every week and pooled into monthly samples for each silage type and replicate. The samples were freeze-dried and milled through a 1-mm screen before chemical analysis. Dry matter (Commission Directive 71/393/EEC; European Economic Community, 1971b), ash (Commission Directive 71/250/EEC; European Economic Community, 1971a), nitrogen $(\mathrm{CP}=6.25 \times \mathrm{N}$, Commission Directive 93/28/EEC; European Economic Community, 1993), crude fat (Commission Directive 98/64/EC; European Economic Community, 1998), starch (procedure 996.11; AOAC, 2000), and fermentation product contents (infrared detector) were determined in feed by standard procedures. Neutral detergent fiber was determined by using an Ankom ${ }^{220}$ fiber analyzer (Ankom Technology, Fairport, NY) with sodium sulfite and $\alpha$ amylase in the neutral detergent, and in vitro DM digestibility was determined according to Tilley and Terry (1963) by using a Daisy ${ }^{\mathrm{II}}$ Incubator (Ankom Technology).

\section{Analysis of Phytoestrogens in Milk and Feed Samples}

Milk samples were deproteinized and defatted by mixing samples $(2.5 \mathrm{~mL})$ with acetate buffer $(0.25 \mathrm{~mL}$; $\mathrm{pH} 5.2 ; 2.0 \mathrm{~mol} / \mathrm{L})$, heptane $(1 \mathrm{~mL})$, and acetone $(2 \mathrm{~mL})$. After centrifugation at $4,000 \times g$ for $10 \mathrm{~min}$, the acetone phase was evaporated to dryness in a vacuum centrifuge at $30^{\circ} \mathrm{C}$ and the residue was dissolved by adding water $(0.8 \mathrm{~mL})$. Conjugates of the phytoestrogens were cleaved by incubating at $40^{\circ} \mathrm{C}$ for $3 \mathrm{~h}$ with $8 \mu \mathrm{L}$ of a mixture of $\beta$-glucuronidase and sulfatase type $\mathrm{H} 2$ from Helix pomatia (Sigma-Aldrich, St. Louis, MO). The solution was added to $0.2 \mathrm{~mL}$ of methanol and centrifuged at $15,000 \times \mathrm{g}$ for $10 \mathrm{~min}$. Feed samples $(0.1 \mathrm{~g})$ were extracted with $5 \mathrm{~mL}$ of a mixture of ethanol and 0.1 $\mathrm{mol} / \mathrm{L}$ acetate buffer, $\mathrm{pH} 5.0(7: 3 \mathrm{vol} / \mathrm{vol})$. The extract was centrifuged at $4,000 \times g$ for $15 \mathrm{~min}$ and the clear supernatant was evaporated to dryness under a gentle stream of nitrogen at $40^{\circ} \mathrm{C}$. The residue was dissolved in $3 \mathrm{~mL}$ of $0.1 \mathrm{~mol} / \mathrm{L}$ acetate buffer, $\mathrm{pH} 5.0$, and incubated with $20 \mathrm{mg}$ of Cellulase Onozuka R-10 (Merck, Darmstadt, Germany) for $16 \mathrm{~h}$ at ambient temperature. After centrifugation at $15,000 \times g$ for $10 \mathrm{~min}$, the clear supernatant was analyzed. All quantifications were performed by using standard addition.

An Agilent HP 1100 HPLC instrument (Agilent, Waldberon, Germany) equipped with a well plate sampler, a thermostated column compartment with columnswitching valve, and a high-pressure binary gradient 
Table 1. Silage clover proportion, chemical composition, feed values, fermentation end products (g/kg of $\mathrm{DM}$, unless stated otherwise), and phytoestrogen content ( $\mathrm{mg} / \mathrm{kg}$ of $\mathrm{DM}$ ) of the experimental feeds

\begin{tabular}{|c|c|c|c|c|c|c|}
\hline \multirow[b]{3}{*}{ Item } & \multicolumn{4}{|c|}{ Silage } & \multirow[b]{3}{*}{ Hay } & \multirow[b]{3}{*}{ Concentrate } \\
\hline & \multicolumn{2}{|c|}{ Period $1^{1}$} & \multicolumn{2}{|c|}{ Period $2^{2}$} & & \\
\hline & WCS & RCS & a & $\mathrm{b}$ & & \\
\hline Clover proportion, $\mathrm{g} / \mathrm{kg}$ of $\mathrm{DM}$ & 295 & 394 & & & & \\
\hline \multicolumn{7}{|l|}{ Chemical composition, $\mathrm{g} / \mathrm{kg}$ of DM } \\
\hline $\mathrm{DM}, \mathrm{g} / \mathrm{kg}$ & 268 & 284 & 314 & 322 & 919 & 886 \\
\hline $\mathrm{CP}$ & 150 & 147 & 122 & 120 & 87 & 159 \\
\hline NDF & 447 & 441 & 493 & 501 & 660 & 216 \\
\hline Crude fat & 42 & 40 & 41 & 15 & 13 & 46 \\
\hline Ash & 92 & 95 & 77 & 73 & 53 & 68 \\
\hline Starch & & & & & & 414 \\
\hline IVDMD $^{3}$ & 749 & 727 & 714 & 786 & 629 & 790 \\
\hline $\mathrm{NE}_{\mathrm{L}}, \mathrm{MJ} / \mathrm{kg}$ of $\mathrm{DM}$ & 6.07 & 5.84 & 5.86 & 6.61 & 5.20 & 6.70 \\
\hline \multicolumn{7}{|l|}{ Fermentation trait, $\mathrm{g} / \mathrm{kg}$ of $\mathrm{DM}$} \\
\hline $\mathrm{pH}$ & 4.6 & 4.8 & 3.7 & 3.7 & & \\
\hline Ammonia $\mathrm{N}, \mathrm{g} / \mathrm{kg}$ of total $\mathrm{N}$ & 67.2 & 66.5 & 44.3 & 46.8 & & \\
\hline Lactic acid & 59.4 & 58.9 & 119.5 & 105.2 & & \\
\hline Acetic acid & 13.7 & 13.6 & 15.8 & 14.9 & & \\
\hline Butyric acid & 0 & 0 & 0 & 0 & & \\
\hline Ethanol & 7.5 & 6.3 & 1.1 & 7.5 & & \\
\hline \multicolumn{7}{|l|}{ Phytoestrogen, $\mathrm{mg} / \mathrm{kg}$ of $\mathrm{DM}$} \\
\hline Secoisolariciresinol & 12.8 & 9.1 & 11.1 & 13.1 & 2.3 & 1.5 \\
\hline Matairesinol & 1.8 & 1.0 & 3.5 & 3.6 & 1.2 & 0.9 \\
\hline Formononetin & 147.1 & 3,039 & 958.1 & 293.3 & 23.4 & 20.7 \\
\hline Daidzein & 19.6 & 90.5 & 37.6 & 18.3 & 0.1 & 0.1 \\
\hline Biochanin A & 23.5 & 2,035 & 482.4 & 98.5 & 0.1 & 0.1 \\
\hline Genistein & 19.8 & 196.1 & 72.9 & 19.3 & 2.4 & 2.6 \\
\hline Prunetin & 1.3 & 245.3 & 65.6 & 12.5 & $<0.1$ & $<0.1$ \\
\hline Coumestrol & 1.7 & 0.15 & 0.3 & 1.1 & 0.2 & 0.2 \\
\hline
\end{tabular}

${ }^{1}$ Period 1: the period when experimental silages were offered; WCS $=$ white clover-grass silage, $\mathrm{RCS}=$ red clover-grass silage.

${ }^{2}$ Period 2, following period 1: all cows received the same silage; $a=$ wk 1 to 4 after period 1 ; $b=$ wk 5 to 7 after period 1 .

${ }^{3}$ IVDMD = in vitro DM digestibility.

pump was used. The flow rate was $0.4 \mathrm{~mL} / \mathrm{min}$, and $50-\mu \mathrm{L}$ samples were injected in the column-switching system. The phytoestrogens were separated on a Zorbax XDB column $(3.5 \mu \mathrm{m}, 2.1 \times 150 \mathrm{~mm})$ by using a gradient between A ( $0.5 \%$ acetic acid) and B (methanol going linearly from $50 \%$ methanol to $74 \%$ methanol) in 14 min. A column-switching system using an Alexa 50 column (Varian Inc., Lake Forrest, CA) was used for online removal of salts and carbohydrates from the sample extracts. A third mobile phase $\mathrm{C}$, consisting of ammonium acetate, $\mathrm{pH}$ 5.2, methanol, and $\mathrm{H}_{2} \mathrm{O}$ (10:200:790 by vol) was pumped at a flow rate of $0.6 \mathrm{~mL} / \mathrm{min}$ with an LKB 2248 pump (Pharmacia, Uppsala, Sweden) through the column-switching system. The HPLC instrument was connected to a Quattro LC MS-MS system from Micromass (Manchester, UK). The settings for the electrospray were desolvation gas $\left(\mathrm{N}_{2}\right) 550 \mathrm{~L} / \mathrm{h}$ at a temperature of $350^{\circ} \mathrm{C}$, capillary voltage $3.0 \mathrm{kV}$, and source temperature $120^{\circ} \mathrm{C}$. For the multiple-reaction monitoring method, argon at a pressure of 2.5 mTorr was used for collision. The cone voltage and the collision energy were set individually for each of the phytoestrogens. To overcome problems with ion suppression or induction, standard addition was used for quantification of phytoestrogens (Hansen-Møller et al., 2007).

Milk samples were analyzed for several different phytoestrogens, some of which were flavonoids (isoflavones, isoflavans, and coumestans) and some of which were nonflavonoids (lignans). The flavonoids analyzed were daidzein, genistein, formononetin, biochanin A, prunetin, equol, and coumestrol. The following nonflavonoids were analyzed: Mata, Seco, enterodiol, and enterolactone. All other chemicals used were of analytical grade and were obtained from Sigma-Aldrich (St. Louis, MO).

\section{Calculation and Statistical Analysis}

Data from the experimental period (period 1) were analyzed by using the MIXED procedure of SAS (SAS Institute, 1999). The following statistical model was used: 
Table 2. Ingredient, nutrient, and phytoestrogen composition of the diets as consumed

\begin{tabular}{|c|c|c|c|c|c|c|}
\hline \multirow[b]{2}{*}{ Item } & \multicolumn{4}{|c|}{ Period $1^{1}$} & \multicolumn{2}{|c|}{ Period $2^{2}$} \\
\hline & WCS0 & WCS1 & RCS0 & $\mathrm{RCS} 1$ & 0 & 1 \\
\hline \multicolumn{7}{|l|}{ Ingredient, g/kg of DM } \\
\hline White clover-grass silage & 984 & 581 & & & & \\
\hline Red clover-grass silage & & & 981 & 578 & & \\
\hline Silage & & & & & 988 & 619 \\
\hline Hay & 15 & 13 & 19 & 15 & 12 & 13 \\
\hline Concentrate & & 406 & & 406 & & 368 \\
\hline \multicolumn{7}{|l|}{ Nutrient, g/kg of DM } \\
\hline $\mathrm{DM}, \mathrm{g} / \mathrm{kg}$ of wet weight & 270 & 378 & 288 & 400 & 320 & 420 \\
\hline $\mathrm{CP}$ & 150 & 153 & 145 & 150 & 121 & 135 \\
\hline $\mathrm{NDF}$ & 449 & 355 & 442 & 351 & 499 & 395 \\
\hline \multicolumn{7}{|l|}{ Phytoestrogen, $\mathrm{mg} / \mathrm{kg}$ of $\mathrm{DM}$} \\
\hline Secoisolariciresinol & 12.7 & 8.3 & 9.5 & 6.1 & 11.7 & 7.9 \\
\hline Matairesinol & 2.1 & 1.6 & 1.4 & 1.2 & 3.5 & 2.5 \\
\hline Formononetin & 147.6 & 96.2 & 3,092 & 1,751 & 683.8 & 436.1 \\
\hline Daidzein & 19.4 & 11.6 & 92.5 & 52.2 & 29.5 & 18.5 \\
\hline Biochanin A & 23.8 & 14.2 & 2,091 & 1,178 & 324.8 & 203.3 \\
\hline Genistein & 19.7 & 12.8 & 201.0 & 114.4 & 50.8 & 32.8 \\
\hline Prunetin & 1.5 & 0.9 & 252.5 & 142.3 & 43.8 & 27.4 \\
\hline
\end{tabular}

${ }^{1}$ Period 1: the period when experimental silages were offered; $\mathrm{WCS} 0=$ white clover-grass silage without concentrate supplementation; WCS1 = white clover-grass silage with concentrate supplementation; RCS0 = red clover-grass silage without concentrate supplementation; RCS1 = red clover-grass silage with concentrate supplementation.

${ }^{2}$ Period 2, following period 1: all cows were offered the same silage but were kept on the same concentrate treatment as in period $1 ; 0=$ none, $1=$ with concentrate supplementation.

$\mathrm{Y}_{\mathrm{ijklm}}=\mu+\mathrm{a}_{\mathrm{i}}+\mathrm{b}_{\mathrm{j}}+(\mathrm{a} \times \mathrm{b})_{\mathrm{ij}}+\mathrm{c}_{\mathrm{k}}+\mathrm{V}\left(\mathrm{e}_{\mathrm{ij}}\right)+\operatorname{cov}\left(\mathrm{f}_{\mathrm{ijk} l m}\right)$

where $Y$ is the dependent variable, $\mu$ is the least squares mean, $a$ is a fixed effect of silage type $i$; $b$ is a fixed effect of concentrate supplementation $j$, and $c$ is a fixed effect of lactation number $\mathrm{k}$. Lactation week was not balanced because the cows calved at different dates and the milk samples were taken at fixed dates. In addition, the effect of lactation week was not significant for most dependent variables. Thus, the effect of lactation week was not included in the model. However, the covariation within animals, $\mathrm{V}\left(\mathrm{e}_{\mathrm{ij}}\right)$, was accounted for in an analysis of repeated measures. The optimal covariance structure, $\operatorname{cov}\left(\mathrm{f}_{\mathrm{ijklm}}\right)$, was assessed for each dependent variable with attention to Akaike's information criterion and Schwarz's Bayesian criterion. Degrees of freedom were estimated by using the formula of Satterthwaite.

When the concentration of phytoestrogens was so low that it could not be detected, the concentration was estimated to be half the detection limit before statistical analysis. Twenty-nine, 7, 2, and 1 milk samples of the 78 collected in period 1 contained no detectable contents of daidzein, biochanin A, prunetin, or Seco, respectively. Coumestrol was detected in only 10 samples and was not subjected to statistical analysis.

Because the residual variance was not constant for most phytoestrogen variables, they were transformed logarithmically (enterolactone, formononetin, daidzein, and equol in milk and formononetin, daidzein, biochanin A, genistein, and prunetin intake) or by square root (enterodiol, biochanin A, prunetin, and genistein in milk) before analysis and predictions. Tests of significance were first made on the transformed scale and then back-transformed to the original scale for presentation. Predicted means on the transformed scale, when back-transformed, give predicted medians on the original scale. Because standard errors are not constant for comparison on the original scale, the results are presented as least square means with pooled standard errors based on the original values. Data from period 2 , the carryover effect period, are presented as means with minimum and maximum values.

\section{RESULTS}

\section{Feed Composition}

The chemical composition and the fermentation characteristics of the experimental feeds are shown in Table 1. Both silage types were well-preserved, with relatively restricted fermentation, and there were only small differences in chemical composition. The WCS had greater in vitro DM digestibility and thus a greater energy value than the RCS. The clover proportion was greater in RCS than in WCS (394 vs. $295 \mathrm{~g} / \mathrm{kg}$ of DM).

The contents of the isoflavones formononetin, biochanin A, genistein, daidzein, and prunetin were 
Table 3. Effect of clover species and concentrate supplementation on feed DMI ( $\mathrm{kg} / \mathrm{d})$, milk yield $(\mathrm{kg} / \mathrm{d})$, and phytoestrogen intake $(\mathrm{g} / \mathrm{d})$

\begin{tabular}{|c|c|c|c|c|c|c|c|c|c|}
\hline \multirow[b]{2}{*}{ Item } & \multicolumn{4}{|c|}{ Treatment $^{1}$} & \multirow[b]{2}{*}{$\mathrm{SEM}^{2}$} & \multicolumn{4}{|c|}{ Significance $^{3}$} \\
\hline & WCS0 & WCS1 & RCS0 & RCS1 & & $\mathrm{F}$ & $\mathrm{C}$ & $\mathrm{F} \times \mathrm{C}$ & $\mathrm{L}$ \\
\hline \multicolumn{10}{|l|}{ DMI, kg/d } \\
\hline Forage (silage and hay) & 13.9 & 12.4 & 14.9 & 11.4 & 0.83 & NS & $* *$ & NS & NS \\
\hline Total & 13.9 & 20.8 & 14.9 & 20.2 & 0.83 & NS & **** & NS & NS \\
\hline Milk yield, kg/d & 21.1 & 27.4 & 22.0 & 26.1 & 1.42 & NS & $* * *$ & NS & **** \\
\hline \multicolumn{10}{|l|}{ Phytoestrogen, g/d } \\
\hline Secoisolariciresinol & 0.172 & 0.165 & 0.147 & 0.121 & 0.0060 & $* * *$ & $*$ & NS & NS \\
\hline Matairesinol & 0.028 & 0.032 & 0.021 & 0.023 & 0.0009 & $* * *$ & $* * *$ & NS & NS \\
\hline Formononetin & 1.97 & 1.88 & 47.0 & 33.7 & 1.46 & $* * *$ & $* * *$ & $* *$ & ** \\
\hline Daidzein & 0.279 & 0.226 & 1.41 & 1.00 & 0.043 & $* * *$ & $* * *$ & * & $* *$ \\
\hline Biochanin A & 0.317 & 0.276 & 31.8 & 22.7 & 1.07 & $* * *$ & $* * *$ & $*$ & ** \\
\hline Genistein & 0.263 & 0.249 & 3.05 & 2.20 & 0.095 & $* * *$ & $* * *$ & $* *$ & ** \\
\hline Prunetin & 0.020 & 0.018 & 3.84 & 2.74 & 0.129 & $* * *$ & $* * *$ & * & $* *$ \\
\hline
\end{tabular}

${ }^{1} \mathrm{WCS} 0$ = white clover-grass silage without concentrate supplementation; $\mathrm{WCS} 1$ = white clover-grass silage with concentrate supplementation; RCS0 = red clover-grass silage without concentrate supplementation; RCS1 = red clover-grass silage with concentrate supplementation.

${ }^{2}$ Pooled SEM for the experimental treatments $(\mathrm{F} \times \mathrm{C})$ based on the original values.

${ }^{3} \mathrm{~F}$ = forage type (white clover-grass silage vs. red clover-grass silage); $\mathrm{C}=$ concentrate supplementation (without vs. with supplementation); $\mathrm{L}=$ lactation number (primiparous vs. multiparous cows).

$* P<0.05 ; * * P<0.01 ; * * * P<0.001 ; \mathrm{NS}=$ not significant $(P>0.1)$.

greater in RCS than in WCS, with formononetin and biochanin A as the predominant isoflavones (Table 1). There were no major differences in the contents of lignans between silage types. Silage content of Seco was greater than that of Mata. Lignan content was below the detection limit in the concentrate, and only small concentrations of isoflavones were detected. The contents of isoflavones and lignans in hay were comparable to those found in the concentrate.

Table 2 summarizes the composition and the nutritive value of the diets. In treatments with supplementation, concentrates accounted for approximately $41 \%$ of the DMI during the forage type experiment (period 1) and $37 \%$ during period 2 . In treatments without concentrate supplementation, silage accounted for $98 \%$ of the DMI. Dietary contents of CP, fiber, and phytoestrogens reflected the silage and concentrate contents. Concentrate supplementation slightly increased the dietary $\mathrm{CP}$ content and reduced the NDF content in both periods. The dietary content of isoflavones was greater and the content of lignans was lower in the RCS than in the WCS diets. Concentrate supplementation reduced the dietary content of all phytoestrogens, but particularly the content of isoflavones.

\section{Feed Intake and Milk Production}

Silage type had no effect on feed intake or milk production (Table 3). On average, concentrate supplementation increased the total daily DMI from 14.4 to 20.5 $\mathrm{kg}$ and the daily milk yield from 21.5 to $26.7 \mathrm{~kg}$ ( $P$
$<0.001$ ). Differences in the intake of phytoestrogens mostly reflected the differences in diet concentrations. In diets with concentrate supplementation, the reduction in isoflavonoid intake was partly counteracted by greater total DMI (Table 3). Supplementation even increased the intake of Mata $(P<0.001)$. The intakes of isoflavones were several times greater in RCS than in WCS $(P<0.001)$, and the intakes of the lignans Seco and Mata were greater in WCS than in RCS $(P<0.001)$.

\section{Milk Phytoestrogen Contents}

Effect of Clover Species on Milk Phytoestrogen Content. Milk concentrations of all isoflavones were higher $(P<0.001)$ in cows offered RCS than in those offered WCS (Table 4). Milk contents of biochanin A, equol, and formononetin were, on average, 5.0, 4.3, and 2.4 times greater, respectively, in RCS than in WCS. Equol was quantitatively the most important. Clover species in silage had no effect on milk contents of the lignans Seco and Mata (Table 4). However, the contents of enterodiol $(P<0.05)$ and enterolactone $(P<0.01)$ were, on average, greater in WCS than in RCS.

Apparent recovery of isoflavones from the diet and into milk was greater $(P<0.001)$ in WCS than in RCS, whereas there was a tendency $(P<0.10)$ for the apparent recovery of lignans to be greater in RCS than in WCS (Table 4).

No apparent carryover effect of red clover from period 1 to 2 was seen because the milk content of isoflavones was similar for all treatments in period 2 , when all 
Table 4. Effect of clover species and concentrate supplementation on milk phytoestrogen content $(\mu \mathrm{g} / \mathrm{L})$

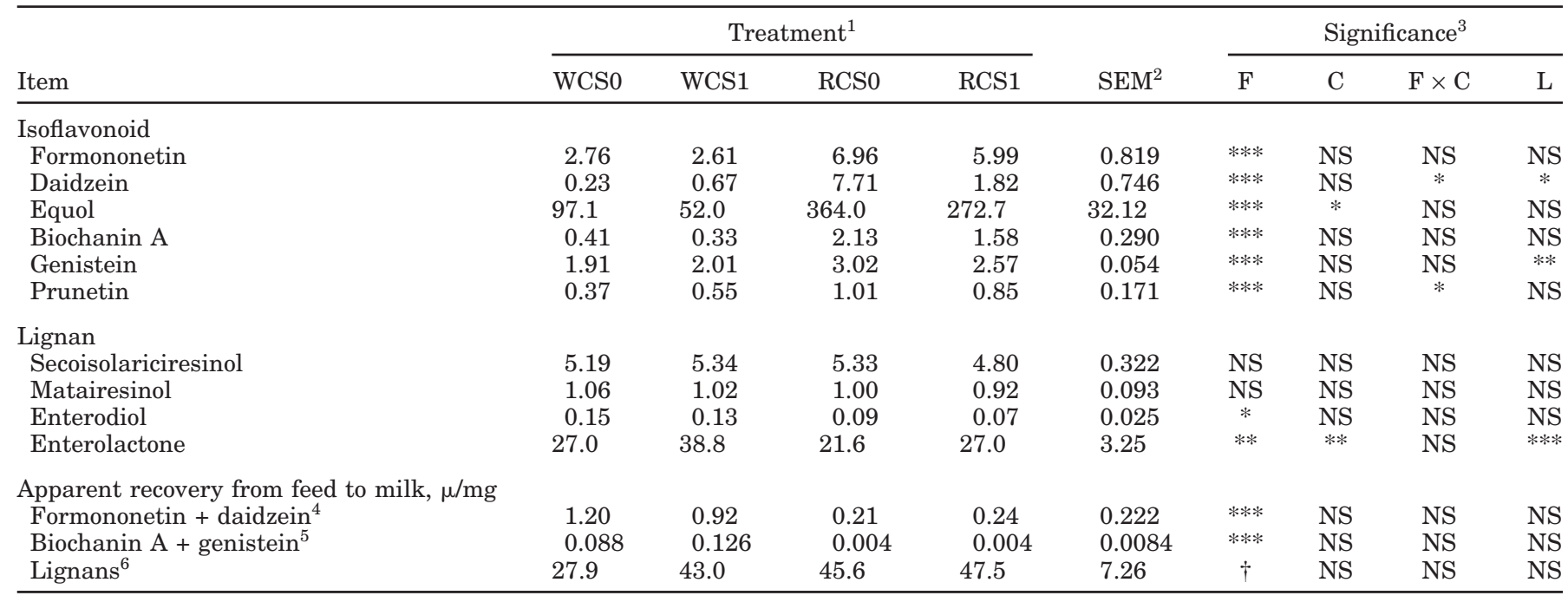

${ }^{1} \mathrm{WCS} 0$ = white clover-grass silage without concentrate supplementation; WCS1 = white clover-grass silage with concentrate supplementation; RCS0 = red clover-grass silage without concentrate supplementation; RCS1 = red clover-grass silage with concentrate supplementation .

${ }^{2}$ Pooled SEM for the experimental treatments $(\mathrm{F} \times \mathrm{C})$ based on the original values.

${ }^{3} \mathrm{~F}$ = forage type (white clover-grass silage vs. red clover-grass silage); $\mathrm{C}=$ concentrate supplementation (without vs. with supplementation); $\mathrm{L}=$ lactation number (primiparous vs. multiparous cows).

${ }^{4}$ (Sum of equol, formononetin, and daidzein secreted in milk)/(sum of formononetin and daidzein intake).

${ }^{5}$ (Sum of biochanin A and genistein secreted in milk)/(sum of biochanin A and genistein intake).

${ }^{6}$ (Sum of secoisolariciresinol, matairesinol, enterodiol, and enterolactone secreted in milk)/(sum of secoisolariciresinol and matairesinol intake).

$\dagger P<0.1 ; * P<0.05 ; * * P<0.01 ; * * * P<0.001 ; \mathrm{NS}=$ not significant $(P>0.1)$.

cows received the same mixed red clover-white clovergrass silage (Table 5). The difference in milk enterodiol and enterolactone contents, as found between silage type treatments in period 1 , was also absent from period 2.

Effect of Concentrate Supplementation on Milk Phytoestrogen Content. Concentrate supplementation reduced the milk equol $(P<0.05)$ content and the milk daidzein $(P<0.05)$ content in RCS diets (Table 4$)$. Milk prunetin content increased with supplementation in WSC and decreased in RSC $(P<0.05)$. Milk contents of lignans were not affected by supplementation, but the content of enterolactone increased $(P<0.05$; Table 4$)$.

Effect of Lactation Number on Milk Phytoestrogen Content. Milk contents of daidzein (2.69 vs. 0.55 $\mu \mathrm{g} / \mathrm{L}, P<0.05)$, genistein (2.66 vs. $2.07 \mu \mathrm{g} / \mathrm{L}, P<0.01$ ), and enterolactone (36.6 vs. $21.4 \mu \mathrm{g} / \mathrm{L}, P<0.001)$ were, on average, greater in primiparous cows than in older cows.

\section{DISCUSSION}

\section{Phytoestrogens in the Feed}

The greater content of isoflavones in RCS than in WCS was expected (Saloniemi et al., 1995; Wu et al.,
2003). The levels of formononetin and biochanin A in RCS in the present study were approximately 40 to $50 \%$ of the levels reported for pure red clover silages (Sarelli et al., 2003; Sivesind and Seguin, 2005; Mustonen et al., 2006). However, our results agree, to a large extent, with those of Kallela (1980), who found between 0.3 and $0.5 \%$ formononetin and $0.2 \%$ biochanin $\mathrm{A}$ in the DM of mixed red clover-grass silages prepared from aftermath cut, as in our study. When taking the clover proportion into account, RCS contents of formononetin and biochanin A were similar to those observed by Sarelli et al. (2003). Thus, the concentrations of formononetin and biochanin A observed in the present study were at a level that may be achieved in mixed RCS. The silage contents of daidzein and genistein were lower than those observed by Sarelli et al. (2003). In the present study, RCS contained more prunetin than daidzein and genistein. To our knowledge, the content of prunetin in silage has not been reported previously.

The concentrate used in the present study was based on whole oat $(600 \mathrm{~g} / \mathrm{kg})$ and barley $(260 \mathrm{~g} / \mathrm{kg})$ grains. These cereal species are known to have low contents of flavonoids but may contain lignans (Adlercreutz and Mazur, 1997; Valsta et al., 2003; Smeds et al., 2007). Adlercreutz and Mazur (1997) found no Mata but found Seco at 0.58 and $0.13 \mathrm{mg} / \mathrm{kg}$ of DM in whole barley and 
Table 5. Mean, minimum $(\min )$, and maximum $(\max )$ content $(\mu \mathrm{g} / \mathrm{L})$ of milk phytoestrogens $(\mu \mathrm{g} / \mathrm{L})$ in period 2 after the silage type experimental period

\begin{tabular}{|c|c|c|c|c|c|c|c|c|c|c|c|c|}
\hline \multirow[b]{2}{*}{ Item } & \multicolumn{3}{|c|}{$\mathrm{WCS} 0^{1}$} & \multicolumn{3}{|c|}{$\mathrm{WCS}^{1}{ }^{1}$} & \multicolumn{3}{|c|}{$\mathrm{RCS}^{1}$} & \multicolumn{3}{|c|}{$\mathrm{RCS}^{1}{ }^{1}$} \\
\hline & Mean & Min & Max & Mean & Min & Max & Mean & Min & Max & Mean & Min & $\operatorname{Max}$ \\
\hline $\mathrm{n}$ & 14 & & & 14 & & & 14 & & & 13 & & \\
\hline Formononetin & 1.53 & 0.39 & 2.45 & 1.62 & 0.15 & 3.00 & 1.48 & 0.20 & 3.16 & 1.51 & 0.08 & 2.88 \\
\hline Daidzein & 1.59 & 0.04 & 2.96 & 1.46 & 0.04 & 4.82 & 2.40 & 0.36 & 4.63 & 1.40 & 0.04 & 4.53 \\
\hline Equol & 55.9 & 33.0 & 101.7 & 69.2 & 25.7 & 99.2 & 69.8 & 24.0 & 126.6 & 63.0 & 22.2 & 124.6 \\
\hline Biochanin A & 0.35 & 0.04 & 1.27 & 0.12 & 0.04 & 0.65 & 0.11 & 0.04 & 0.63 & 0.26 & 0.04 & 1.44 \\
\hline \multicolumn{13}{|l|}{ Lignan } \\
\hline Secoisolariciresinol & 4.61 & 0.20 & 26.2 & 2.63 & 0.20 & 6.31 & 8.13 & 4.54 & 23.3 & 3.06 & 0.20 & 5.96 \\
\hline Matairesinol & 0.37 & 0.38 & 1.16 & 0.58 & 0.07 & 1.57 & 0.77 & 0.45 & 1.31 & 0.41 & 0.07 & 1.62 \\
\hline Enterodiol & 0.09 & 0.04 & 0.26 & 0.08 & 0.03 & 0.14 & 0.07 & 0.01 & 0.20 & 0.06 & 0.01 & 0.15 \\
\hline Enterolactone & 19.0 & 9.7 & 40.3 & 48.0 & 20.0 & 77.5 & 21.0 & 10.2 & 48.3 & 47.4 & 22.3 & 184.5 \\
\hline
\end{tabular}

${ }^{1}$ All cows received the same silage but remained in the same concentrate treatment group as in period 1 . The annotation refers to the treatments in period 1 , the silage type experimental period. WCS0 $=$ white clover-grass silage without concentrate supplementation; WCS1 = white clover-grass silage with concentrate supplementation; RCS0 = red clover-grass silage without concentrate supplementation; RCS $1=$ red clover-grass silage with concentrate supplementation.

oat meals, respectively. Smeds et al. (2007) reported both Mata (4.40 and $0.42 \mathrm{mg} / \mathrm{kg}$ of DM) and Seco (0.90 and $0.42 \mathrm{mg} / \mathrm{kg}$ of $\mathrm{DM}$ ) in the bran of oats and barley.

The reported concentrations of Mata and Seco in grains are low compared with the concentrations found in the silage in our study. To our knowledge, the contents of lignans in silage have not been reported before, and the results indicate that forage is more important than oats and barley grain for the intake of the lignans Seco and Mata.

\section{Phytoestrogens in the Milk}

Phytoestrogens are highly metabolized by microorganisms in the rumen and gut (Cox and Braden, 1974; Borriello et al., 1985; Lundh, 1995). Thus, the relatively high milk contents of equol and enterolactone compared with their precursors (formononetin and daidzein for equol, and Mata, Seco, and enterodiol for enterolactone) were expected. To our knowledge, this is the first time that the apparent recovery of phytoestrogens from feed to milk has been reported. The mechanism explaining the difference in recovery is not clear because we have no intermediate observation of the metabolism. However, one explanation could be that the metabolism (conjugation) in the gastrointestinal tract and the hepatic reconjugation before blood transport and secretion into the udder could be rate limited, resulting in a higher transfer rate with low intake of isoflavones (WCS) than with high intake (RCS). The epithelial cells in the mammary gland might be only slightly permeable to estrogenic compounds, as suggested by Turner (1958).
The average milk content of each individual isoflavone in the present study was higher than the average content found in previous studies (Adlercreutz et al., 1985; King et al., 1998; Antignac et al., 2004; Purup et al., 2005), but levels were similar to others in milk from cows on certain diets (King et al., 1998; Antignac et al., 2004; Purup et al., 2005; Hoikkala et al., 2007). King et al. (1998) found, on average, $293 \mu \mathrm{g} / \mathrm{L}$ of equol in milk collected from farms on which the dairy cows were grazing high-flavonoid-containing subterranean clover (Trifolium subterraneum). Antignac et al. (2004), Purup et al. (2005), and Hoikkala et al. (2007) found 191, 230, and $411 \mu \mathrm{g} / \mathrm{L}$ of equol in milk from organic production, respectively, whereas comparable milk samples form conventional production contained 36,41 , and $62 \mu \mathrm{g} /$ $\mathrm{L}$ of equol. Because of the importance of legumes for nitrogen fixation in crop rotation, the diets of the dairy cows on organic farms usually have a higher content of leguminous feedstuffs, in particular clovers from forage, than in conventional production. Higher content of flavonoids is therefore expected in organically produced milk. However, this is highly dependent on the composition of the diets, including clover species. Purup et al. (2005) observed significant variation in the contents of isoflavones in bulk milk from different farms. In the present study, higher equol levels were found in milk from cows on the red clover-based diets, in contrast to milk from cows on the white clover-based diets. The content of equol in milk from the white clover diets was similar to what has been reported for conventionally produced milk (Adlercreutz et al., 1985; King et al., 1998; Antignac et al., 2004; Purup et al., 2005). The very high equol content found in organic Finnish milk 
was also likely due to the widespread use of red clover in grassland, and thus in the diet of dairy cows in Finnish organic dairy production (Hoikkala et al., 2007). Sakakibara et al. (2003) observed as much as $1.7 \mathrm{mg} / \mathrm{L}$ of equol in cow's milk when feeding pure red clover silage.

Higher milk contents of the mammalian lignans enterodiol and enterolactone in the WCS diets were likely due to higher dietary content and intake of their precursors. Whether this is because white clover has a higher content of lignans than red clover, or that the proportion of grass was higher in WCS diets and grass has a higher content of lignans than clovers, warrants further study.

The reducing effect of concentrate supplementation on milk contents of equol, daidzein, and prunetin in RCS and the elevating effect on prunetin in WCS was likely due to differences in intake of formononetin (the precursor of daidzein and equol), daidzein (the precursor of equol), and prunetin. The lack of effect of concentrate on milk biochanin A and genistein may be because biochanin A and genistein, to a large extent, have been metabolized to $p$-ethyl phenol (not determined) in the rumen (Lundh et al., 1990; Lundh, 1995). This is supported by the low apparent transfer rates of biochanin A and genistein from feed to milk and that supplementation had no effect on these transfer rates (Table 4). The milk content of enterolactone in the milk from concentrate-supplemented cows was similar to the level found by Antignac et al. (2004). However, the mechanism for the elevating effect of supplementation on the content of milk enterolactone is obscure. Enterolactone is, like equol, an end product from rumen or gut microbial metabolism. However, contents of the precursors, Mata and Seco (Borriello et al., 1985), could not be detected in the concentrate used, and therefore do not explain the increasing effect of concentrate on enterolactone. Smeds et al. (2007) recently managed to quantify 7-hydroxymatairesinol in cereals, a plant lignan that, because of destructive extraction methods, had not been detected in cereals before. Moreover, they showed that this compound was the dominant lignan in oats and barley. In a previous work, Heinonen et al. (2001) demonstrated that hydroxymatairesinol is metabolized in vitro by human fecal flora to enterolactone. Therefore, it is possible that the elevating effect of concentrate supplementation was due to a greater intake of hydroxymatairesinol, which we were not able to detect. However, this hypothesis remains to be tested.

Greater contents of daidzein, prunetin, and enterolactone in milk from primiparous cows than from multiparous cows might be a concentration effect (relatively higher intake of phytoestrogens per kilogram of milk produced). Primiparous cows yielded significantly less milk but had approximately the same total feed intake as multiparous cows (figures not shown).
The observed milk content of phytoestrogens in the present study was low compared with food sources rich in phytoestrogens, such as soy milk, which is reported to have a total isoflavone content of 13 to $211 \mathrm{mg} / \mathrm{kg}$ (Reinli and Block, 1996). However, it has been demonstrated that phytoestrogens may affect the endocrine system, even at low concentrations. Almstrup et al. (2002) found that some phytoestrogens at low doses inhibited aromatise, an enzyme that catalyzes the conversion of testosterone to $17 \beta$-estradiol, but were estrogenic at higher concentrations. The high content of equol in milk from cows in RCS is particularly interesting because it is superior to other isoflavones in its antioxidant activity (Mitchell et al., 1998), has a far greater affinity to estrogen receptors than its precursor daidzein (Setchell et al., 2002), and acts as an antagonist of dihydrotestosterones, which may have implications for the prevention of prostate cancer and other androgen-related conditions (Lund et al., 2004). Furthermore, increasing concentrations of equol have been shown to decrease proliferation and prostate-specific antigen concentrations in human prostate cancer cells (Adlercreutz, 2002). The clinical effectiveness of soy or other high-daidzein-containing products is believed to be dependent on the ability to metabolize daidzein to equol. However, approximately 30 to $50 \%$ of the adult population is not able to produce equol from daidzein, likely because of the large interindividual variability of the intestinal flora (Rowland et al., 2000). Therefore, dairy milk with an elevated equol content may be interesting as a dietary source of equol, if equol is demonstrated to have the suggested salutary effects. The form of equol may also be important. It is exclusively the enantiomeric form, S-equol, that is produced in humans, and it is S-equol, and not the other chiral form R-equol, that has relatively high affinity for estrogen receptor $\beta$ (Setchell et al., 2005). We did not try to separate the 2 equol enantiomers. However, it is likely that it was the biologically effective S-equol, because Mustonen et al. (2006) found that sheep produce only this form.

\section{CONCLUSIONS}

Diets containing RCS yielded milk with a high content of isoflavonoids in general, and of equol in particular, compared with WCS. Supplementation with a standard concentrate reduced the contents of equol and other flavonoids, but the level was still high compared with white clover-containing diets. Concentrate supplementation increased the content of mammalian lignans, but this increase could not be explained by the intake of known precursors. There are likely other lignans in oats or barley (the main components of the 
concentrate used) that we were unable to analyze that caused the concentrate-induced increase in mammalian lignans. Finally, milk content of flavonoids is easily manipulated by the choice of legume species that can be used to produce milk with specific or desired characteristics.

\section{ACKNOWLEDGMENTS}

The authors are grateful to the staff at the Animal Production Centre, Norwegian University of Life Sciences, for technical assistance and care of the experimental animals, Claes-Gøran Fristedt at the Department of Animal and Aquacultural Sciences, Norwegian University of Life Sciences, for feed and milk sampling, and the laboratory staff at the University of Aarhus for chemical analysis of feed and milk. Thanks are also due to Torfinn Torp at the Department of Chemistry, Biotechnology and Food Science, for statistical assistance and to Karl N. Kerner for the improvement of our English language. This work was financially supported by the Norwegian Agricultural Authority (Oslo, Norway).

\section{REFERENCES}

Adams, N. R. 1995. Detection of the effects of phytoestrogens on sheep and cattle. J. Anim. Sci. 73:1509-1515.

Adlercreutz, H. 2002. Phyto-oestrogens and cancer. Lancet Oncol. 3:364-373.

Adlercreutz, H., T. Fotsis, C. Bannwart, T. Mäkelä, K. Wähälä, G. Brunow, and T. Hase. 1985. Assay of lignans and phytoestrogens in urine of women and in cow milk by GC/MS (SIM). Pages 12931294 in Advances in Mass Spectrometry. J. F. J. Todd, ed. John Wiley and Sons, New York, NY.

Adlercreutz, H., H. Honjo, A. Higashi, T. Fotsis, E. Hamalainen, T. Hasegawa, and H. Okada. 1991. Urinary excretion of lignans and isoflavonoid phytoestrogens in Japanese men and women consuming a traditional Japanese diet. Am. J. Clin. Nutr. 54:1093-1100.

Adlercreutz, H., and W. Mazur. 1997. Phyto-oestrogens and Western diseases. Ann. Med. 29:95-120.

Almstrup, K., M. F. Fernandez, J. H. Petersen, N. Olea, N. E. Skakkebaek, and H. Leffers. 2002. Dual effects of phytoestrogens result in U-shaped dose-response curves. Environ. Health Perspect. 110:743-748.

Antignac, J.-P., R. Cariou, B. Le Bizec, and F. André. 2004. New data regarding phytoestrogens content in bovine milk. Food Chem. $87: 275-281$.

AOAC. 2000. Official Methods of Analysis. 17th ed. Assoc. Anal. Chem., Arlington, VA.

Bennetts, H. W., E. J. Underwood, and F. L. Shier. 1946. A specific breeding problem of sheep on subterranean clover pastures in Western Australia. Aust. J. Agric. Res. 22:131-138.

Borriello, S. P., K. D. R. Setchell, M. Axelson, and A. M. Lawson. 1985. Production and metabolism of lignans by the human fecal flora. J. Appl. Bacteriol. 58:37-43.

Cornwell, T., W. Cohick, and I. Raskin. 2004. Dietary phytoestrogens and health. Phytochemistry 65:995-1016.

Cox, R. I., and A. W. Braden. 1974. The metabolism and physiological effects of phyto-oestrogens in livestock. Proc. Aust. Soc. Anim. Prod. 10:122-129.
Dickinson, J. M., G. R. Smith, R. D. Randel, and I. J. Pemberton. 1988. In vitro metabolism of formononetin and biochanin A in bovine rumen fluid. J. Anim. Sci. 66:1969-1973.

European Economic Community. 1971a. First Commission Directive 71/250/EEC of 15 June 1971 establishing Community methods of analysis for the official control of feeding-stuffs. Off. J. Eur. Commun. L155:13-37.

European Economic Community. 1971b. Second Commission Directive 71/393/EEC of 18 November 1971 establishing Community methods of analysis for the official control of feedingstuffs. Off. J. Eur. Commun. L279:7-18.

European Economic Community. 1993. Commission Directive 93/28/ EEC of 4 June 1993 amending Annex I to the third Directive 72/ 199/EEC establishing Community methods of analysis for the official control of feedingstuffs. Off. J. Eur. Commun. L179:8-10.

European Economic Community. 1998. Corrigendum to Commission Directive 98/64/EC of 3 September 1998 establishing Community methods of analysis for the determination of amino-acids, crude oils and fats, and olaquindox in feedingstuffs and amending Directive 71/393/EEC. Off. J. L275:14-28.

Hansen-Møller, J., H. Steinshamn, E. Thuen, and S. Purup. 2007. Development and validation of a liquid chromatographic method for determination of phytoestrogens in dairy milk. Poster presented at Am. Soc. Mass Spectr. Symp., Indianapolis, IN.

Heinonen, S., T. Nurmi, K. Liukkonen, K. Poutanen, K. Wahala, T. Deyama, S. Nishibe, and H. Adlercreutz. 2001. In vitro metabolism of plant lignans: New precursors of mammalian lignans enterolactone and enterodiol. J. Agric. Food Chem. 49:3178-3186.

Hilakivi-Clarke, L., E. Cho, S. deAssis, S. Olivo, E. Ealley, K. B. Bouker, J. N. Welch, G. Khan, R. Clarke, and A. Cabanes. 2001. Maternal and prepubertal diet, mammary development and breast cancer risk. J. Nutr. 131:154S-157S.

Hoikkala, A., E. Mustonen, I. Saastamolnen, T. Jokela, J. Taponen, H. Saloniemi, and K. Wahala. 2007. High levels of equol in organic skimmed Finnish cow milk. Mol. Nutr. Food Res. 51:782-786.

Kallela, K. 1980. The estrogenic effect of silage fodder. Nord. Vet. Med. 32:480-486.

Kallela, K., K. Heinonen, and H. Saloniemi. 1984. Plant oestrogens: The cause of decreased fertility in cows. A case report. Nord. Vet. Med. 36:124-129.

King, R. A., M. M. Mano, and R. J. Head. 1998. Assessment of isoflavonoid concentrations in Australian bovine milk samples. J. Dairy Res. 65:479-489.

Lund, T. D., D. J. Munson, M. E. Haldy, K. D. R. Setchell, E. D. Lephart, and R. J. Handa. 2004. Equol is a novel anti-androgen that inhibits prostate growth and hormone feedback. Biol. Reprod. 70:1188-1195.

Lundh, T. 1995. Metabolism of estrogenic isoflavones in domestic animals. Proc. Soc. Exp. Biol. Med. 208:33-39.

Lundh, T. J. O. 1990. Conjugation of the plant estrogens formononetin and daidzein and their metabolite equol by gastrointestinal epithelium from cattle and sheep. J. Agric. Food Chem. 38:10121016.

Lundh, T. J. O., H. I. Pettersson, and K. A. Martinsson. 1990. Comparative levels of free and conjugated plant estrogens in blood-plasma of sheep and cattle fed estrogenic silage. J. Agric. Food Chem. 38:1530-1534.

McMurray, C. H., A. S. Laidlaw, and M. McElroy. 1986. The effect of plant development and environment on formononetin concentration in red clover (Trifolium pratense L.). J. Sci. Food Agric. 37:333-340.

Mendez, M. A., M. S. Anthony, and L. Arab. 2002. Soy-based formulae and infant growth and development: A review. J. Nutr. 132:2127-2130.

Mitchell, J. H., P. T. Gardner, D. B. McPhail, P. C. Morrice, A. R. Collins, and G. G. Duthie. 1998. Antioxidant efficacy of phytoestrogens in chemical and biological model Systems. Arch. Biochem. Biophys. 360:142-148.

Mustonen, E. A., T. Jokela, I. Saastamoinen, J. Taponen, S. Taponen, H. Saloniemi, and K. Wahala. 2006. High serum S-equol content in red clover fed ewes: The classical endocrine disruptor is a single enantiomer. Environ. Chem. Lett. 3:154-159. 
Purup, S., J. Hansen-Møller, K. Sejrsen, L. P. Chritsensen, A. E. Lykkesfeldt, H. Leffers, and N. E. Skakkebæk. 2005. Increased phytoestrogen content in organic milk and the biological importance. Newsletter from Danish Research Centre for Organic Farming, June 2005, No 2. http://www.darcof.dk/enews/jun05/ milk.html Accessed Nov. 9, 2007.

Reinli, K., and G. Block. 1996. Phytoestrogen content of foods-A compendium of literature values. Nutr. Cancer 26:123-148.

Rowland, I. R., H. Wiseman, T. A. B. Sanders, H. Adlercreutz, and E. A. Bowey. 2000. Interindividual variation in metabolism of soy isoflavones and lignans: Influence of habitual diet on equol production by the gut microflora. Nutr. Cancer 36:27-32.

Sakakibara, H., D. Viala, M. Doreau, and J. M. Besle. 2003. Clover isoflavones move to cows' milk. Pages 296 in 1st Int. Conf. Polyphenols and Health, Vichy, France. INRA, St-Genes-Champanelle, France.

Saloniemi, H., K. Wahala, P. Nykänen-Kurki, K. Kallela, and I. Saastamoinen. 1995. Phytoestrogen content and estrogenic effect of legume fodder. Proc. Soc. Exp. Biol. Med. 208:13-17.

Sarelli, L., M. Tuori, I. Saastamoinen, L. Syrjala-Qvist, and H. Saloniemi. 2003. Phytoestrogen content of birdsfoot trefoil and red clover: Effects of growth stage and ensiling method. Acta Agric. Scand. Anim. Sci. 53:58-63.

SAS Institute. 1999. SAS/STAT Software. Release 8.02. SAS Institute Inc., Cary, NC.

Setchell, K. D. R., N. M. Brown, and E. Lydeking-Olsen. 2002. The clinical importance of the metabolite equol-A clue to the effectiveness of soy and its isoflavones. J. Nutr. 132:3577-3584.

Setchell, K. D. R., C. Clerici, E. D. Lephart, S. J. Cole, C. Heenan, D. Castellani, B. E. Wolfe, L. Nechemias-Zimmer, N. M. Brown, T. D. Lund, R. J. Handa, and J. E. Heubi. 2005. S-Equol, a potent ligand for estrogen receptor $\beta$, is the exclusive enantiomeric form of the soy isoflavone metabolite produced by human intestinal bacterial floral. Am. J. Clin. Nutr. 81:1072-1079.

Sivesind, E., and P. Seguin. 2005. Effects of the environment, cultivar, maturity, and preservation method on red clover isoflavone concentration. J. Agric. Food Chem. 53:6397-6402.

Smeds, A. I., P. C. Eklund, R. E. Sjoholm, S. M. Willfor, S. Nishibe, T. Deyama, and B. R. Holmbom. 2007. Quantification of a broad spectrum of lignans in cereals, oilseeds, and nuts. J. Agric. Food Chem. 55:1337-1346.

Smith, J. F., and K. T. Jagusch. 1979. Coumestans in Lucerne and ovulation in ewes. N. Z. J. Agric. Res. 22:411-416.

Tham, D. M., C. D. Gardner, and W. L. Haskell. 1998. Potential health benefits of dietary phytoestrogens: A review of the clinical, epidemiological, and mechanistic evidence. J. Clin. Endocrinol. Metab. 83:2223-2235.

Thompson, L. U., P. Robb, M. Serraino, and F. Cheung. 1991. Mammalian lignan production from various foods. Nutr. Cancer 16:43-52.

Tilley, J. M. A., and R. A. Terry. 1963. A two stage technique for the in vitro digestion of forage crops. J. Br. Grassl. Soc. 18:104-111.

Tuohy, P. G. 2003. Review Article. Soy infant formula and phytoestrogens. J. Paediatr. Child Health 39:401-405.

Turner, C. W. 1958. Estrogen content of colostrum and milk of dairy cattle. J. Dairy Sci. 41:630-640.

Valsta, L. M., A. Kilkkinen, W. Mazur, T. Nurmi, A. M. Lampi, M. L. Ovaskainen, T. Korhonen, H. Adlercreutz, and P. Pietinen. 2003. Phyto-oestrogen database of foods and average intake in Finland. Br. J. Nutr. 89:S31-S38.

Wu, Q., M. Wang, and J. E. Simon. 2003. Determination of isoflavones in red clover and related species by high-performance liquid chromatography combined with ultraviolet and mass spectrometric detection. J. Chromatogr. A 1016:195-209.

Zung, A., R. Reifen, Z. Keem, and Z. Zadik. 2001. Phytoestrogens: The pediatric perspective. J. Pediatr. Gastroenterol. Nutr. 33:112-118. 